\title{
Treatment of Biomass Gasification Wastewaters Using Liquid-Liquid Extraction
}

N. E. Bell

September 1981

Prepared for the U.S. Department of Energy under Contract DE-AC06-76RLO 1830

Pacific Northwest Laboratory Operated for the U.S. Department of Energy by Battelle Memorial Institute 


\title{
NOTICE
}

This report was prepared as an account of work sponsored by the United States Government. Neither the United States nor the Department of Energy, nor any of their employees, nor any of their contractors, subcontractors, or their employees, makes any warranty, express or implied, or assumes any legal liability or responsibility for the accuracy. completeness or usefulness of any information, apparatus, product or process disclosed, or represents that its use would not infringe privately owned rights.

The views, opinions and conclusions contained in this report are those of the contractor and do not necessarily represent those of the United States Government or the United States Department of Energy.

\author{
PACIFIC NORTHWEST LABORATORY \\ operated by \\ BATTELLE \\ for the \\ UNITED STATES DEPARTMENT OF ENERGY \\ Under Contract DE-AC06-76RLO 1830
}

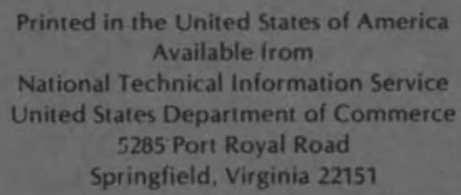

Price: Printed Copy $\$$

$\because$ Microfiche $\$ 3.00$

NTIS

-Pages Selling Price

001-025 \$4.00

026-050 \$4.50

051-075 \$5.25

076-100 $\quad \$ 6.00$

$101-125 \quad \$ 6.50$

126-150 \$7.25

$151-175 \quad \$ 8.00$

$176-200 \quad \$ 9.00$

$201.225 \quad 59.25$

$226-250 \quad \$ 9.50$

$251-275 \quad \$ 10.75$

276-300 $\$ 11.00$ 
TREATMENT OF BIOMASS GASIFICATION WASTEWATERS USING LIQUID-LIQUID EXTRACTION

\section{N.E. Be11}

September 1981

Prepared for the U.S. Department of Energy Under Contract No. DE-AC06-76RL0-1830

Pacific Northwest Laboratory Richland, Washington 99352 


\section{DISCLAIMER}

Use of brand or trade names in this report does not constitute endorsement by the U.S. Department of Energy or Pacific Northwest Laboratory.

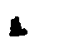

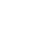




\section{PREFACE}

This report is one of a series prepared by Pacific Northwest Laboratory for the U.S. Department of Energy on treatment of biomass gasification wastewaters. Other reports have dealt with carbon adsorption, biological oxidation, reverse osmosis, and wet air oxidation. All the reports include results of experimental work on a laboratory scale. Wastewater used in these studies came from the experimental Synthesis Gas From Manure (SGFM) biomass gasifier at Texas Tech University. 


\section{ACKNOWLEDGMENTS}

I wish to thank Marie Laegreid for performing the COD analyses, Scott Eliason for general laboratory assistance, and Nancy Painter for typing the manuscript.

I greatly appreciate the efforts of Gary Roberts and Wayne Wilcox, of the Chemical Technology Department, who performed the gas chromatography analyses.

I also wish to thank Dr. Steven Beck, of Texas Tech University, for providing the wastewater samples and Ray Costello, of the Biomass Energy System Division, U.S. Department of Energy, for funding this project. 


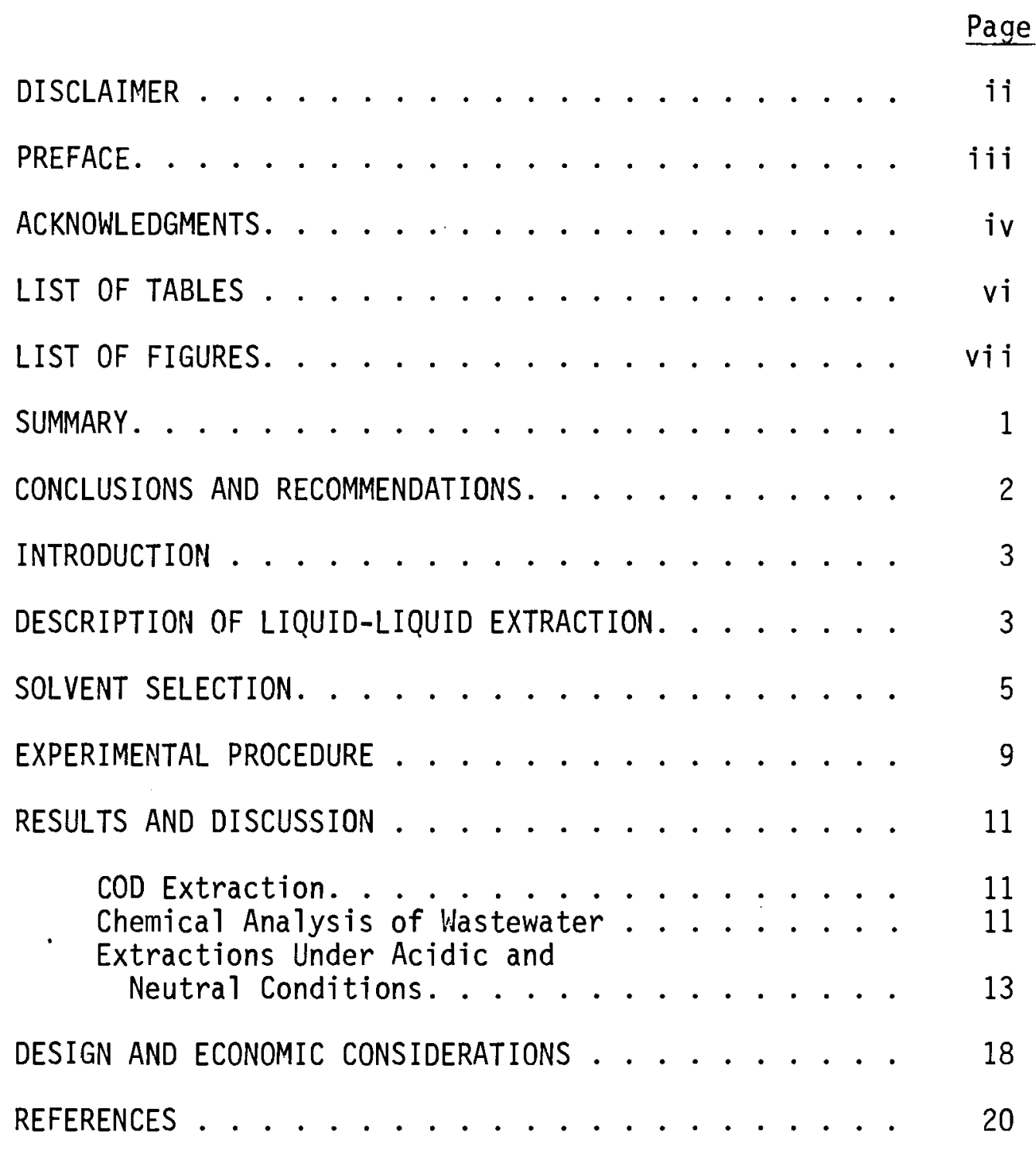




\section{LIST OF TABLES}

No. $\quad$ Page

1 Analyses of Biomass Gasification Wastewater. . . . . . 4

2 Properties of Solvents Used in This Work . . . . . 8

3 Extraction of COD by Various Solvents......... 11

4 Chemical Analys is of Wastewater by Gas Chromatography, mg/1 ........... 13

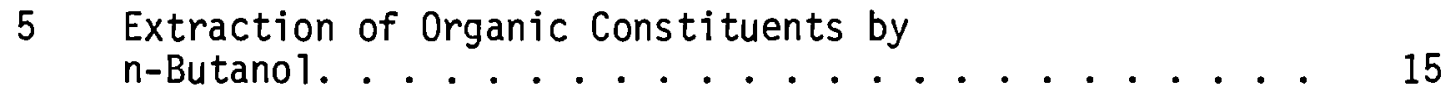

6 Extraction of Organic Constituents by MIBK ................. 16 


\section{LIST OF FIGURES}

No. $\quad$ Page

1 Typical Solvent Extraction Process . . . . . . . 6

2 Titration of Biomass Gasification Wastewater (BGW 6)............ 10 
. 


\section{SUMMARY}

Pacific Northwest Laboratory (PNL) investigated liquid-liquid extraction as a treatment method for biomass gasification wastewaters (BGW). Distribution coefficients for chemical oxygen demand (COD) removal were determined for the following solvents: methylisobutyl ketone (MIBK), n-butyl acetate, n-butanol, MIBK/n-butyl acetate (50:50 vol), MIBK/n-butanol (50:50 vol), tri-butyl phosphate, tri-n-octy 1 phosphine oxide (TOPO)/MIBK (10:90 wt), TOPO/kerosene (10:90 wt), kerosene, and toluene. The best distribution coefficient of 1.3 was given by $n$-butanol.

Chemical analysis of the wastewater by gas chromatography (GC) showed acetic acid and propionic acid concentrations of about $4000 \mathrm{mg} / 1$. Methanol, ethanol, and acetone were identified in trace amounts. These five compounds accounted for $45 \%$ of the measured COD of $29,000 \mathrm{mg} / 1$.

Because of the presence of carboxylic acids, $\mathrm{pH}$ was expected to affect extraction of the wastewater. At low pH the acids should be in the acidic form, which increased extraction by MIBK. Extraction by $n$ butanol was increased at high $\mathrm{pH}$, where the acids should be in the ionic form. 
PNL identified individual components of BGW by GC, accounting for $45 \%$ of the measured COD. Acetic and propionic acid were present in the highest concentrations.

Of the solvents tested for liquid-liquid extraction of the wastewater, n-butanol had the best distribution coefficient (1.3) for COD. The use of n-butanol as a solvent would require a complicated regeneration process. Use of another solvent (such as $n$-pentanol) with a lower distribution coefficient but a simpler regeneration process would probably be more cost effective.

Acetic acid extraction by MIBK was better at low pH. The increase is probably not enough to justify the cost of acidification.

Overal1, a promising liquid-liquid extraction process has not yet been identified. Results from wet air oxidation, biological oxidation, and reverse osmosis experiments in this laboratory are much more promising. Any additional research should be focused on these three processes. In addition, the compounds causing the remainder of the COD should be identified in order to improve design of these processes. 


\section{LIQUID-LIQUID EXTRACTION OF \\ BIOMASS GASIFICATION WASTEWATER}

\section{INTRODUCTION}

Liquid-liquid extraction (or solvent extraction) has been proposed as a treatment method for wastewater from biomass gasification processes. In these processes, solid biomass (typically wood chips or manure) is heated in the presence of air and steam. The major product is a lowheating-value synthesis gas containing hydrogen, methane, ethane, carbon monoxide, and carbon dioxide. By-products include tar and a darkcolored aqueous phase heavily contaminated with organic compounds. This aqueous phase must be treated before release to the environment.

Wastewater samples obtained from the Synthesis Gas From Manure (SGFM) biomass gasifier at Texas Tech University, Lubbock, Texas, show wide variations in composition, including $\mathrm{pH}$ and $\mathrm{COD}$ (Table 1). The wastewater used in this study (BGW 6) had a pH of 7.4 and a COD of $29,000 \mathrm{mg} / 1$. The major organic contaminants are reported to be carboxylic acids (Kao 1980).

DESCRIPTION OF LIQUID-LIQUID EXTRACTION

Liquid-liquid extraction was considered for treatment of this wastewater for severa 1 reasons:

- Extraction is relatively insensitive to fluctuations in concentration. Wide fluctuations in BGW composition are expected because of natural variations in biomass feedstock composition and process modifications during development of the biomass gasification process.

- Extraction is not affected by toxic compounds. Maxham (1981) reports limits in the allowable organic loading rates of various biological reactors because of toxic compounds in biomass wastewater.

- A wide variety of solvents can be used. As a result, the process can be tailored to the specific wastewater components.

- The pollutants can be recovered and sold, thus partially offsetting the cost of wastewater treatment. 
TABLE 1. Analyses of Biomass Gasification Wastewater

\begin{tabular}{|c|c|c|c|c|c|c|c|}
\hline & BGW $1^{1}$ & BGW $2^{1}$ & BGW $3^{1}$ & BGW $4^{1}$ & BGW $5^{1}$ & $\mathrm{BGW} 6^{2}$ & $\mathrm{KaO}^{3}$ \\
\hline $\mathrm{pH}$, Standard Units & 3.9 & 3.5 & 3.7 & 5.5 & 4.0 & 7.4 & 2.3 \\
\hline Chemical 0xygen Demand, $\mathrm{mg} / 1$ & 45,800 & 43,600 & 47,600 & 67,900 & 32,800 & 28,700 & 43,960 \\
\hline Total Organic Carbon, $\mathrm{mg} / 1$ & 15,200 & 15,300 & 16,700 & 22,900 & 10,900 & $12,730^{4}$ & \\
\hline $\begin{array}{l}\text { Total Kjeldahl (Organic) } \\
\text { Nitrogen, } \mathrm{mg} / 1\end{array}$ & - & 200 & 95 & 5,462 & 157 & $5,690^{4}$ & \\
\hline Total $\mathrm{NH}_{3}-\mathrm{Ni}$ trogen, $\mathrm{mg} / 1$ & 194 & 18 & 16 & 2,330 & 32 & 236 & \\
\hline $\begin{array}{l}1_{\text {Maxham } 1981 .} \\
{ }^{2} \text { This work. } \\
{ }^{3} \text { Kao } 1980 . \\
{ }^{4} \text { English } 1981 .\end{array}$ & & & & & & & \\
\hline
\end{tabular}


Extraction processes are usually not capable of reducing pollutant aqueous phase concentrations below about $10 \mathrm{mg} / 1$, and a polishing step such as biological oxidation, reverse osmosis, or carbon adsorption may be required (Kiezyk and Mackay 1971).

Extraction costs tend to be proportional to the amount of water treated, while biological oxidation and carbon adsorption tend to be proportional to the amount of contaminant removed; thus, liquid-liquid extraction is more cost effective at high concentrations.

Liquid-liquid extraction processes are generally composed of three parts -- extraction, solvent regeneration, and solvent recovery (Figure 1). In the extraction step, wastewater and immiscible solvent are mixed and separated. The contaminants are transferred from the wastewater to the solvent. In the solvent regeneration step, the pollutants are separated from the solvent so the solvent can be recycled to the extractor. The low volume concentration streams of pollutants may be recycled to the process, disposed of, or purified for resale. In the solvent recovery step, residual solvent is removed from the treated wastewater and recycled. This step may not be necessary for solvents with low solubility in water.

\section{SOLVENT SELECTION}

The technical and economic feasibility of an extraction system strongly depends on the solvent selected. Selection is based on the extractive ability of the solvent, ease of regeneration, density, solubility in water, viscosity and interfacial tension, price and availability, chemical stability, and safety and toxicity.

A number of solvents have been tested for industrial scale extraction of acetic acid, one of the major constituents of the wastewater. These solvents have been basic, containing an oxygen, nitrogen, or phosphorous group to draw the acid. Brown (1963) investigated the economics of extraction of acetic acid from cellulose acetate, pulpmi11, and other wastewaters. He found that ketones, esters, and ethers were most effective. Weaver and Biggs (1961) reported that of the oxygenated compounds they tested, methyl ethyl ketone was the most effective for extraction of formic and acetic acid from pulpmill (NSSC process) liquor. A mixture (3:1 by vol) of isopropyl acetate and isopropyl alcohol was the 


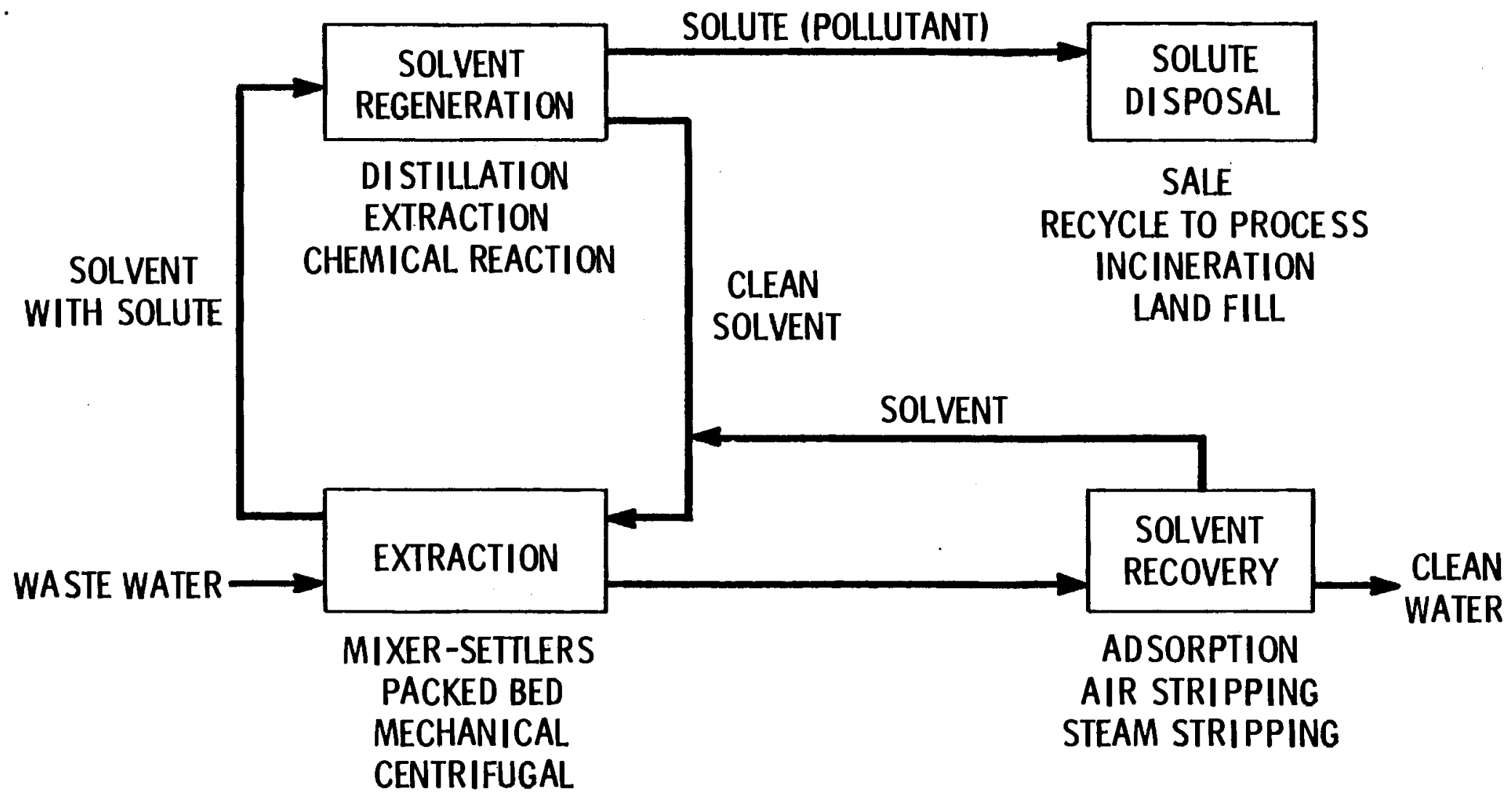

FIGURE 1. Typical Solvent Extraction Process 
second best. Wardell and King (1978) found that phosphoryl and tertiary amine solvents were more effective for acetic acid extraction than ethers, esters, ketones, and alcohols. Hydroscience, Inc. offers an acetic acid extraction process using tri-n-octyl phosphine oxide (TOPO) in a kerosene-like diluent (Helsel 1977, Kohn 1976).

A solvent that works well on one type of wastewater would not necessarily be the best solvent for BGW because the biomass wastewater is a complex mixture of many organic compounds. A variety of commercially available solvents were chosen for laboratory testing. MIBK, n-butyl acetate, and n-butanol were selected as examples of oxygenated (and therefore polar and basic) solvents that are typically used for acid removal. Mixtures of MIBK and $n$-butanol ( $1: 1$ by vol) and MIBK and $n-$ butyl acetate ( $1: 1$ by vol) were also tested. The extractive ability of mixtures is frequently greater than that of any of the components due to the nonideality of the solvent-water combination.

Two phosphoryl compounds -- tri-n-butyl phosphate (TBP) and TOPO -were selected as solvents. TBP is relatively inexpensive and has been used for treatment of coke plant wastewater (Kiezyk and Mackay 1971). TOPO is much more expensive but is also much more effective. The solubility of TOPO in water is less than 1 ppm. TOPO is a solid at ambient temperatures and must be diluted. Kerosene was chosen as a diluent based on the Hydroscience process. TOPO was soluble in kerosene to about $10 \mathrm{wt} \%$. A solvent recovery step would not be required for TOPO/ kerosene because the solubilities are so low. TOPO was also diluted in MIBK because TOPO is more soluble in polar organic solvents (Wardell and King 1978). However, TOPO/MIBK formed an emulsion with water (distilled or wastewater) at TOPO concentrations above about $10 \mathrm{wt} \%$ TOPO in MIBK. Therefore, TOPO was diluted to $10 \mathrm{wt} \%$ in each dilutent.

In addition, toluene and kerosene were tested to determine if they would remove the nonacidic higher molecular weight compounds which were toxic to bacteria in the biological reactors. Both have very low solubilities in water. Physical properties of the solvents tested are given in Table 2. 
TABLE 2. Properties of Solvents Used in This Work ${ }^{1}$

\begin{tabular}{|c|c|c|c|c|c|}
\hline Solvent & Formula & $\begin{array}{c}\text { Boiling Point, } \\
{ }^{\circ} \mathrm{C} \\
\end{array}$ & $\begin{array}{c}\text { Density, } \\
\mathrm{g} / \mathrm{ml} \\
\end{array}$ & $\begin{array}{l}\text { Solubility in Water, } \\
\text { parts } / 100 \text { parts wt }\end{array}$ & Manufacturer (Grade) \\
\hline MIBK & $\mathrm{C}_{6} \mathrm{H}_{12} \mathrm{O}$ & $117-119$ & 0.801 & 2 & Chem West \\
\hline n-Butyl acetate & $\mathrm{C}_{6} \mathrm{H}_{12} \mathrm{O}_{2}$ & 126.1 & 0.88 & 0.7 & Baker (Food) \\
\hline n-Butanol & $\mathrm{C}_{4} \mathrm{H}_{10} \mathrm{O}$ & 118.0 & 0.81 & 9 & Amachem (Reagent) \\
\hline TBP & $\left(\mathrm{C}_{4} \mathrm{H}_{9} \mathrm{O}\right)_{3} \mathrm{PO}$ & 289 Decomposes & 0.976 & 0.6 & Kodak (Chemical) \\
\hline TOPO & $\left(\mathrm{C}_{8} \mathrm{H}_{17}\right)_{3} \mathrm{PO}$ & $56_{\mathrm{MP}}, 460_{\mathrm{BP}}^{4}$ & & $0.0001^{4}$ & Kodak (Chemical) \\
\hline Kerosene & $\mathrm{C}_{n} \mathrm{H}_{2 n+2} \operatorname{mix}$ & $150-300$ & $0.79^{3}$ & 0.002 (octane) & $\begin{array}{l}\text { Sargent Welch } \\
\text { (Deodorized) }\end{array}$ \\
\hline Toluene & $\mathrm{C}_{7} \mathrm{H}_{8}$ & 110.6 & 0.866 & $0.05^{2}$ & $\begin{array}{l}\text { Matheson Coleman Bell } \\
\text { (Spectroscopic) }\end{array}$ \\
\hline MIBK/n-butyl acetate & & & $0.83^{3}$ & & \\
\hline MIBK/n-butanol & & & $0.80^{3}$ & & \\
\hline TOPO/Kerosene & & & $0.77^{3}$ & & \\
\hline TOPO/MIBK & & & $0.81^{3}$ & & \\
\hline $\begin{array}{l}{ }^{1} \text { Dean } 1973 . \\
{ }^{2} \text { Perry } 1973 . \\
{ }^{3} \text { This Work. } \\
{ }^{4} \text { Helsel } 1977 .\end{array}$ & & & & & \\
\hline
\end{tabular}


EXPERIMENTAL PROCEDURE

The extractive ability of each of the solvents for BGW was determined experimentally. The extractive ability is measured by the distribution coefficient, defined as the ratio at equilibrium of solute concentration in the organic phase to solute concentration in the aqueous phase.

BGW 6 from the Texas Tech University SGFM reactor was used in this study. The wastewater was filtered (Whatman No. 1 filter paper) and stored at $4^{\circ} \mathrm{C}$ upon receipt.

Each extraction was performed by combining $50 \mathrm{~m} 7$ of solvent or solvent mixture and $25 \mathrm{ml}$ of wastewater in a separatory funnel and shaking for 5 min. The two phases were allowed to gravity settle for at least $2 \mathrm{hrs}$. Samples of the aqueous and organic phase were stored in glass bottles at $4^{\circ} \mathrm{C}$ until chemical analyses could be performed.

In the first set of experiments the COD of the aqueous phase was used to determine the extent of extraction. Values of COD were measured in duplicate by the procedure specified in Standard Methods for the Examination of Water and Wastewater (APHA 1975). A blank extraction with distilled water and solvent was performed to determine the solvent contribution to the COD of extracted wastewater. The COD of the wastewater feed was also determined.

A second set of experiments was run to test the effect of $\mathrm{pH}$ on extraction. Titration of the wastewater with $1 \mathrm{~N} \mathrm{H}_{2} \mathrm{SO}_{4}$ indicated that $13.5 \mathrm{ml} / 100 \mathrm{ml}$ wastewater (Figure 2) would be required to reduce the $\mathrm{pH}$ to one unit below the $\mathrm{pK}_{\mathrm{a}}$ of acetic acid $\left(\mathrm{pK}_{\mathrm{a}}=4.76\right)$ (Dean 1973). This is the equivalent of 0.21 tons concentrated sulfuric acid per 1000 gal of wastewater. Note that the titration did not show the usual inflection point at the $\mathrm{pk}_{\mathrm{a}}$.

Extractions with standard $(\mathrm{pH}=7.5)$ and acidified $(\mathrm{pH}=3.6)$ wastewater with $n$-butanol and MIBK as solvents were made in the manner described above. GC was used to identify individual components of the wastewater before and after extraction. A Hewlett-Packard 5830 GC with a SP 1200 column $\left(1 / 4^{\prime \prime} \times 6^{\prime}\right.$ glass) and a flame ionization detector was used. Isopropyl alcohol was added to the samples as an internal standard. 


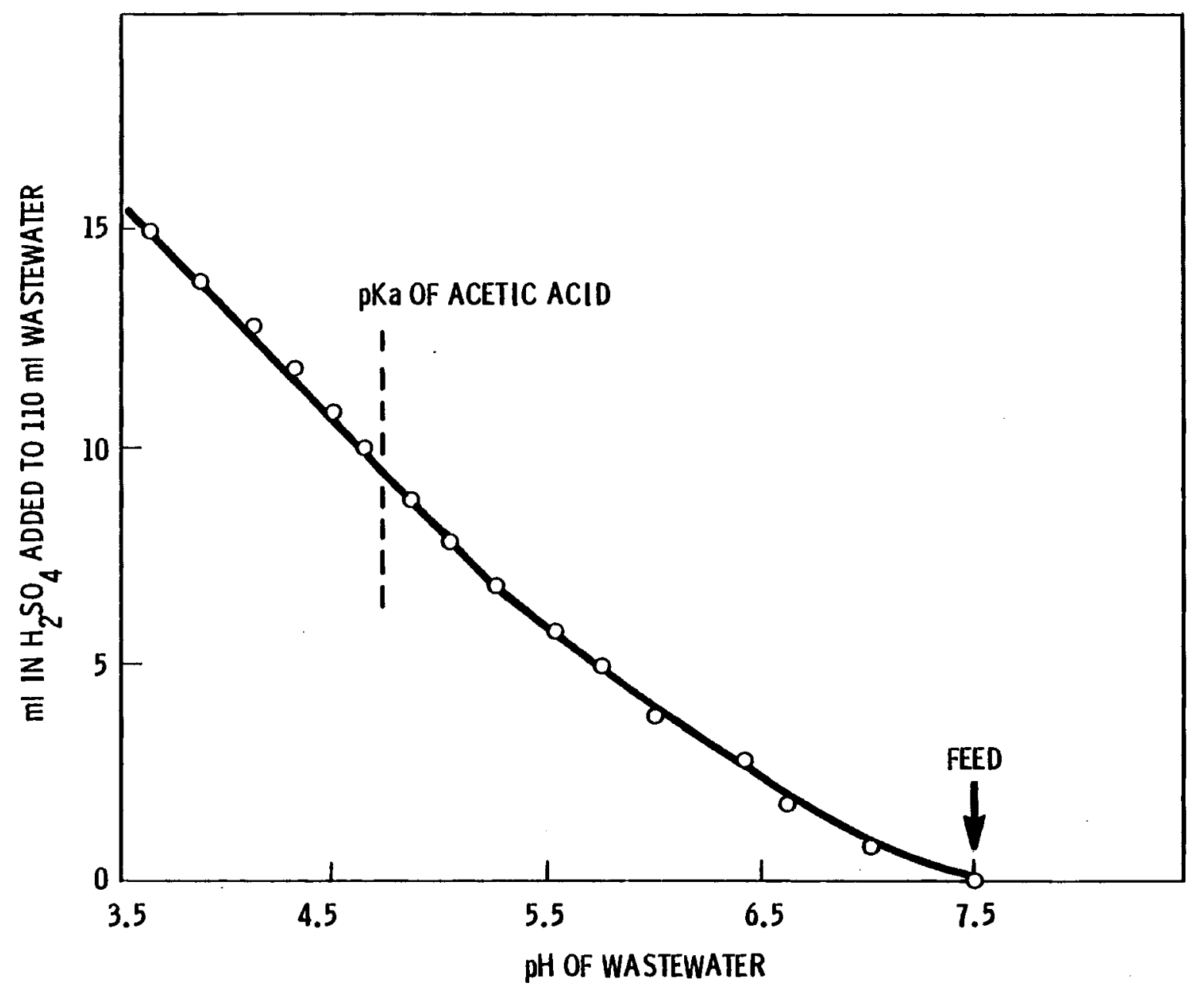

FIGURE 2. Titration of Biomass Gasification Wastewater (BGW 6) 
RESULTS AND DISCUSSION

COD Extraction

The results of the COD extraction tests are shown in Table 3 . The measured solvent contribution to COD was, in all cases except TOPO/ kerosene, less than the theoretical oxygen demand of the solvent based on the solvent's solubility in water. This comparison serves as a check on the COD analyses. The COD may be low because of incomplete COD reactions, imprecise solubility measurements, or incomplete equilibrium between phases. The solubility of TOPO in water is less than $1 \mathrm{ppm}$, so its contribution to COD should be negligible. It is suspected that impurities in the TOPO (also found in earlier work by Bell 1980) were responsible for the increased COD. Both TOPO/kerosene and TOPO/MIBK show an increase in solvent COD over than of the diluent alone.

Distribution coefficients (the ratio of organic phase concentration to aqueous phase concentration) were calculated by assuming a complete material balance closure. The equilibrium aqueous phase COD value (denominator) was determined by subtracting the solvent contribution to the COD from the total COD after extraction. In an industrial process, the solvent contribution to the $C O D$ would be removed in the solvent recovery step. The equilibrium organic phase COD value (numerator) was calculated by subtracting the equilibrium aqueous phase COD (after extraction) from the COD value of the aqueous feed.

The only solvent with a distribution coefficient greater than unity was n-butanol with a $K_{D}$ of 1.28 (Table 3 ). A $K_{D}$ greater than unity is desired in order to keep solvent-to-feed ratios low and reduce regeneration costs. The MIBK/n-butanol mixture was next best with a $K_{D}$ of 0.46 . After n-butanol, the phosphoryl solvents were best; TOPO/MIBK had a $K_{D}$ of 0.27 and TBP had $a K_{D}$ of 0.16 . All other solvents gave a distribution coefficient less than 0.1 . The difference between the TOPO/MIBK coefficient (0.27) and the TOPO/kerosene coefficient (0.09) shows the positive effect of a polar diluent, which probably gives a higher solubility for the polar TOPO reaction complex.

Chemical Analysis of Wastewater

Because of the low distribution coefficients for COD in various solvents, GC was used to determine the organic chemical components of 
TABLE 3. Extraction of COD by Various Solvents

\begin{tabular}{|c|c|c|c|c|}
\hline Solvent & $\begin{array}{l}\text { Theoretical 0xygen } \\
(\mathrm{TH} .0 \mathrm{D}), 1 \mathrm{mg} / 1\end{array}$ & $\begin{array}{c}\text { Measured COD of } \\
\text { Solvent in Distilled } \\
\text { Water, } 2 \mathrm{mg} / 1 \\
\end{array}$ & $\begin{array}{l}\text { Measured COD of } \\
\text { Wastewater After } \\
\text { Extraction, } 2 \mathrm{mg} / 1\end{array}$ & $\begin{array}{c}\text { Distribution } \\
\text { Coefficient, } \\
\frac{\mathrm{mg} / 1}{\mathrm{mg} / \mathrm{l}} \\
\end{array}$ \\
\hline MIBK & 53,333 & 31,355 & 59,490 & $0.0097 \pm 0.021$ \\
\hline n-Butyl acetate & 15,362 & 9,001 & 33,104 & $0.095 \pm 0.015$ \\
\hline n-Butanol & 213,853 & 167,647 & 175,705 & $1.28 \pm 0.66$ \\
\hline MIBK/n-buty 1 acetate & 53,333 & 19,608 & 46,412 & $0.035 \pm 0.017$ \\
\hline MIBK/n-butano 1 & 213,853 & 115,883 & 130,785 & \pm 0.13 \\
\hline TBP & 13,479 & 1,489 & 23,628 & \pm 0.014 \\
\hline TOPO/Kerosene & 70 (octane) & 500 & 25,098 & $0.092 \pm 0.012$ \\
\hline TOPO/MIBK & 53,333 & 35,651 & 55,532 & \pm 0.031 \\
\hline Kerosene & 70 (octane) & 24 & 25,195 & $0.088 \pm 0.012$ \\
\hline Toluene & 1,561 & 128 & 25,861 & $0.057 \pm 0.012$ \\
\hline
\end{tabular}

Th.0D $=$ Th.0D of pure solvent $x$ solubility in water. If a mixture, the higher of the two Th.0Ds was given.

${ }^{2}$ The standard deviation for 16 samples averaged $1.59 \pm 0.91 \%$ of the mean of two analyses.

${ }^{3}$ Feed $\mathrm{COD}=28,682 \mathrm{mgO}_{2} / 1$ solution

$$
\begin{aligned}
& K_{D}=\frac{\text { Concentration Organic Phase }}{\text { Concentration Aqueous Phase }}=\left[\frac{C O D \text { of Feed }-(C O D \text { of Aqueous Phase }- \text { COD of Solvent) }}{\text { COD of Aqueous Phase - COD of Solvent }}\right] \times\left[\frac{\text { Vol of Aqueous Phase }}{\text { Vol of Organic Phase }}\right. \\
& \text { Example (n-butyl acetate): } \quad K_{D}=\frac{28,682-(33,104-9,001)}{33,104-9,001} \times \frac{25}{50}=0.095
\end{aligned}
$$

Error was determined using an average standard deviation of $1.59 \%$ of each COD analysis. 
the wastewater (BGW 6 in Table 4). Methanol, ethanol, acetone, and acetic acid were quantitatively identified. Propionic acid was clearly identified although the amount could not be determined because of interferences. Due to GC operating conditions, formic acid could not be measured. The components identified account for only 13,000 $\mathrm{mg} / 1$ of the measured $29,000 \mathrm{mg} / 1 \mathrm{COD}$. Presumably the remaining $\mathrm{COD}$ is caused by the presence of higher molecular weight compounds which gave high retention times but could not be separated. Siller (1976) found butanoic acid, pivalic acid, ethyl benzene, $n$-propyl benzene, isobutyl benzene, t-butyl benzene, biphenyl, anthracene, cis-decalin, trans-decalin, fluoranthene, and pyrene in BGW from the Texas Tech gasifier.

Table 4 also shows a GC analysis of a BGW performed by Kao (1980). Amounts of methanol, ethanol, and acetone were about the same. However, he reports a much higher quantity of acetic acid $(26,150 \mathrm{mg} / 1)$ than shown by the GC analysis at PNL $(4000 \mathrm{mg} / 1)$. He was also able to account for $99 \%$ of the COD of his wastewater. Since the two wastewaters vary considerably in $\mathrm{COD}$ and $\mathrm{pH}$, it is probable that the difference in acetic acid concentration is due to real differences in the wastewater rather than difficulties in the GC analysis.

The GC analysis showed the presence of large amounts of carboxylic acids. Because the $\mathrm{pH}$ of the wastewater (7.32) was higher than the $\mathrm{pK}_{\mathrm{a}}$ of the acids (about 4.8 for acetic and propionic acid), the acids would be present as anions. Since this has been reported to adversely affect extraction by basic solvents (Greminger 1979), the wastewater was acidified with sulfuric acid to $\mathrm{pH} 3.7$. At this $\mathrm{pH}$ greater than $90 \%$ of the acids should be in the acid form. A GC analysis of the acidified wastewater indicated a decrease in concentrations of the minor components methanol, ethanol, and acetone, due to either changes in ionic form (e.g., hydrogen bonding) or reaction with sulfuric acid.

Extractions Under Acidic and Neutral Conditions

Extractions of both neutral and acidified wastewater were performed with $n$-butanol and MIBK to determine the effect of $\mathrm{pH}$. Concentrations and distributions coefficients are shown in Tables 5 and 6 for n-butanol and MIBK, respectively. Several of the numbers in Tables 5 and 6 are questionable due to difficulties in reproduction of GC analyses. 
TABLE 4. Chemical Analyses of Wastewater by Gas Chromatography, $\mathrm{mg} / 1$

\begin{tabular}{|c|c|c|c|}
\hline & BGW 6 & $\begin{array}{l}\text { Acidified } \\
\text { BGW } 6 \\
\end{array}$ & $\mathrm{KaO}^{1}$ \\
\hline Methanol & $1,480 \pm 75$ & $1,070 \pm 49$ & 3,382 \\
\hline Acetone & $280 \pm \quad 28$ & $110 \pm 14$ & 660 \\
\hline Ethanol & $580 \pm \quad 35$ & $300 \pm 7$ & 394 \\
\hline Acetic Acid & $3,980 \pm 116$ & $3,750 \pm 640$ & 26,150 \\
\hline Propionic Acid & $3,026 \pm 2,690$ & - & 6,161 \\
\hline Formic Acid & - & - & 488 \\
\hline $\mathrm{pH}$, Standard Units & 7.32 & 3.68 & 2.27 \\
\hline $\begin{array}{l}\text { Calculated COD } \\
\text { (Excluding Propionic Acid) }\end{array}$ & $\begin{array}{r}12,880 \pm 4,066 \\
8,306 \pm 193\end{array}$ & - & 43,586 \\
\hline Measured COD & 28,682 & - & 43,960 \\
\hline
\end{tabular}


TABLE 5. Extraction of Organic Constituents by n-Butano1

\begin{tabular}{|c|c|c|c|c|c|c|c|c|c|}
\hline \multirow[b]{3}{*}{ Methanol } & \multicolumn{4}{|c|}{ Concentration, $\mathrm{mg} / 1$} & \multicolumn{5}{|c|}{ Distribution Coefficients, $\frac{\mathrm{mg} / \mathrm{l}}{\mathrm{mg} / \mathrm{l}}$} \\
\hline & $\begin{array}{c}\text { BGW } 6 \\
\text { Feed (Neutral) }\end{array}$ & $\begin{array}{l}\text { Wastewater } \\
\text { Extract (Neutra1) }\end{array}$ & $\begin{array}{c}\text { BGW } 6 \\
\text { Feed (Acldic) }\end{array}$ & $\begin{array}{l}\text { Wastewater } \\
\text { Extract (Acidic) }\end{array}$ & Neutral & Acid & Perry ${ }^{3}$ & $\underline{\text { Leo }}{ }^{4}$ & $\underline{\mathrm{Kao}}{ }^{5}$ \\
\hline & $1,480 \pm 75$ & 790 & $1,065 \pm 49$ & $577 \pm$ & $0.44 \pm 0.047$ & $0.42 \pm 0.062$ & 0.41 & - & 5.59 \\
\hline Acetone & $280 \pm \quad 28$ & $40 \pm \quad 57$ & $110 \pm 14$ & $83 \pm$ & $3.0 \pm 4.3$ & $0.16 \pm 0.20$ & - & - & 1.21 \\
\hline Ethanol & $580 \pm 35$ & $155 \pm$ & $295 \pm 7$ & $240 \pm$ & $1.37 \pm 0.74$ & $0.11 \pm 0.22$ & 2.43 & - & 2.35 \\
\hline Acetic Acid & $3,980 \pm 116$ & $3,800 \pm 2,300$ & $3,750 \pm 640$ & $5,900 \pm 2,400$ & $0.019 \pm 6.3$ & 0 & 1.31 & 1.09 & 1.30 \\
\hline Propionic Acid & $3,000 \pm 2,700$ & - & - & - & - & - & - & 1.67 & 2.50 \\
\hline COD & 28,700 & $8,058^{1}$ & - & - & 1.28 & & & & \\
\hline $\begin{array}{l}\mathrm{pH}, \text { Standard } \\
\text { Units }\end{array}$ & 7.32 & 7.72 & 3.68 & 4.28 & & & & & \\
\hline n-Butanol & 0 & $78,380^{2}$ & 0 & $72,000 \pm 14,000^{2}$ & & & & & \\
\hline
\end{tabular}

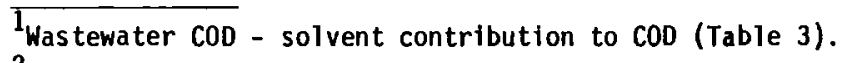

${ }^{2}$ Maximum based on solubility is 82,600 .

3 Perry 1973.

${ }^{4}$ Leo 1971

${ }^{5} \mathrm{Kao} 1980(\mathrm{pH}=2.3)$. 


\section{TABLE 6. Extraction of Organic Constituents by MIBK}

\begin{tabular}{|c|c|c|c|c|c|c|c|c|c|}
\hline \multirow[b]{3}{*}{ Methanol } & \multicolumn{4}{|c|}{ Concentration, $\mathrm{mg} / \mathrm{l}$} & \multicolumn{5}{|c|}{ Distribution Coefficients, $\frac{\mathrm{mg} / \mathrm{l}}{\mathrm{mg} / \mathrm{I}}$} \\
\hline & $\begin{array}{c}\text { BGW } 6 \\
\text { Feed (Neutral) }\end{array}$ & $\begin{array}{c}\text { Wastewater } \\
\text { Extract (Neutral) }\end{array}$ & \multirow{2}{*}{$\begin{array}{c}\text { BGW 6 } \\
\text { Feed (Acidic) } \\
1,065 \pm 49\end{array}$} & \multirow{2}{*}{$\begin{array}{c}\text { Wastewater } \\
\text { Extract (Acidic) } \\
945 \pm 78\end{array}$} & Neutral & \multicolumn{2}{|c|}{ Acid } & \multirow{2}{*}{ Perry ${ }^{3}$} & \multirow{2}{*}{$\underline{\text { Leo }}^{4}$} \\
\hline & $1,480 \pm$ & $1,050 \pm$ & & & $0.20 \pm 0.051$ & 0.063 & \pm 0.049 & & \\
\hline Acetone & $280 \pm$ & $240 \pm$ & $110 \pm 14$ & $275 \pm 35$ & $0.083 \pm 0.13$ & & $\mathbf{0}$ & 1.53 & - \\
\hline Ethanol & $580 \pm$ & $230 \pm$ & $295 \pm 7$ & $115 \pm 21$ & $0.76 \pm 0.40$ & 0.78 & \pm 0.17 & - & - \\
\hline Acetic Acid & $3,980 \pm 116$ & $3,840 \pm 1,075$ & $3,750 \pm 640$ & $1,710 \pm 115$ & $0.018 \pm 0.14$ & 0.60 & \pm 0.20 & $\begin{array}{l}0.53 \\
0.60\end{array}$ & 0.73 \\
\hline Propionic Acid & $3,000 \pm 2,700$ & - & - & - & - & & - & 1.949 & 1.23 \\
\hline COD & 28,700 & $28,135^{1}$ & - & - & 0.0097 & & & & \\
\hline $\begin{array}{l}\text { pH, Standard } \\
\text { Units }\end{array}$ & 7.32 & 7.83 & 3.68 & 3.82 & & & & & \\
\hline MIBK & 0 & $13,200 \pm 800^{2}$ & 0 & $14,500 \pm 900^{2}$ & & & & & \\
\hline
\end{tabular}

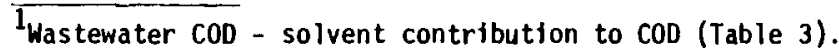

${ }^{2}$ Maximum based on solubility is 19,600 .

3 Perry 1973.

${ }^{4}$ Leo 1971. 
The concentrations of butanol in the wastewater extracts (Table 5) were about $90 \%$ of the reported maximum solubility, indicating that the extractions were close to equilibrium. Methanol had a distribution coefficient of 0.4 under acidic and basic conditions. The $K_{D}$ for acetone appeared to drop steeply at low pH; however, due to large errors in analysis, this cannot be confirmed. The $K_{D}$ for ethanol also dropped, al though the high $\mathrm{pH}$ value was much closer to literature values. Acetic acid was not extracted under either acidic or neutral conditions, contrary to literature predictions of a $K_{D}$ of 1.3 for single component acetic acid solutions. The reasons for this are unknown. Perhaps other components in the wastewater competed for the oxygen atom on the solvent molecule. However, less than $10 \%$ of the oxygen atoms should have been used during complete hydrogen bonding (1:1 stoichiometric basis) with the wastewater components. Minor constituents may also have affected the surface tension and thus the ability of acetic acid to tansfer to the organic phase. Propionic acid appeared to be poorly extracted also. In general, acid conditions seemed to decrease extraction of the wastewater by n-butanol.

In Table 6 the concentration of MIBK in the wastewater extractions was about $70 \%$ of maximum solubility. This may indicate that the extractions by MIBK did not reach complete equilibrium. However, the COD $K_{D}$ for MIBK is so low a $30 \%$ increase would make little difference. The extractions of both methanol and acetone were decreased by low $\mathrm{pH}$, while that of ethanol was not affected. On the other hand, acetic acid extraction is significantly increased $\left(K_{D}=0.6\right)$ at low $\mathrm{pH}$. The acidic $K_{D}$ matches literature values. Since acetic acid is in much higher concentrations than methanol, acetone, and ethanol, acidification of the wastewater might be more economical than using high solvent-to-feed ratios. Propionic and other acids are assumed to have the same $\mathrm{pH}$ response.

It should be noted that the $\mathrm{pH}$ rose upon extraction by both butanol and MIBK under both neutral and acidic conditions. Therefore, some acid was being extracted in all four experiments although the identity of the $\operatorname{acid}(\mathrm{s})$ remained unknown. 


\section{DESIGN AND ECONOMIC CONSIDERATIONS}

The best solvent tested was n-butanol with a $K_{D}$ of 1.3 for COD. However, process design is complicated by two factors: n-butanol and water form an azeotrope which boils at $92^{\circ} \mathrm{C}$, and $n$-butanol and acetic acid boil at about the same temperature $\left(118^{\circ} \mathrm{C}\right)$. Thus, n-butanol and acetic acid would have to be separated by some other means -- probably extraction with water and purification.

A simpler process could be used if iso-butanol were the solvent. Iso-butanol and water form an azeotrope boiling at $90^{\circ} \mathrm{C}$. However, once water has been removed, iso-butanol $\left(T_{B}\right.$ of $\left.107^{\circ} \mathrm{C}\right)$ and acetic acid can be separated by distillation. Leo (1971) reports distribution coefficients of 1.09 for acetic acid into either n-butanol or iso-butanol. Therefore, $K_{D}$ for COD should be similar for the two solvents. The distribution coefficient for the wastewater by iso-butanol should be experimentally determined before proceeding with design work.

n-Pentanol should also have similar distribution coefficients for the wastewater, although $K_{D}$ 's would be lower because of the higher molecular weight. Again, experimental measurements are required. Use of n-pentanol would avoid the azeotrope problem. In addition, the solubility of $n$-pentanol in water would be less, reducing the amount of solvent recovery required.

Actual costs depend on the solvent selected and process design. If a solvent such as MIBK, which works best under acidic conditions ( $\mathrm{pH}$ less than $\mathrm{pK}_{\mathrm{a}}$ ) is used, then the cost of acidification must be included. For BGW 6, 0.21 tons of sulfuric acid per 1000 gals would be required to reduce the $\mathrm{pH}$ to 3.6. The cost of sulfuric acid ranges from $\$ 18$ to $\$ 80$ per ton (CMR 1981) for a charge of $\$ 3.86$ to $\$ 17.18$ per $1000 \mathrm{gal}$. The wastewater might also have to be neutralized before release.

One of the advantages of liquid-liquid extraction is that the pollutants can be recovered and sold. Although purification of a pollutant will add extra processing steps, the cost of these are usually justified by credit for the sale of the pollutant. If $99 \%$ of the acetic acid (at $3980 \mathrm{mg} / 1$ ) is recovered and sold at $\$ 0.26$ per 1b (Chemical Marketing Reporter 1981), $\$ 8.54 / 1000$ gal could be credited to the extraction process. 
The two major costs of a liquid-liquid extraction system are operation of the solvent regeneration (distillation) tower and amortization of equipment. Reducing the solvent-to-wastewater ratio in the extractor and increasing the size (number of stages) of the extraction column usualty reduces total costs (Hanson 1968). Liquid-liquid extraction costs vary widely with the application. Helsel (1976) claimed costs of $\$ 0.20$ per 1000 gal for extraction of acetic acid from pharmaceutical wastewater. Earhart et a1., (1976) report cost estimates of $\$ 0.71$ per 1000 gal for extraction of n-buty 1 acetate by isobutylene and $\$ 1-3$ per 1000 gal for extraction of diethylene dichloride by isobutylene. Lyman (1978) estimated a cost of $\$ 10.76$ per 1000 gal for extraction of phenol by toluene. Similarly, Lorton (1978) estimated a cost of $\$ 10.76$ per 1000 gal for extraction of phenolics from coal gasification wastewater by methy 1 isobutyl ketone. Thus, a rough estimate of costs for extraction of biomass gasification wastewater would be $\$ 1-10$ per 1000 gat. 


\section{REFERENCES}

American Public Health Association, American Water Works Association, and Water Pollution Control Federation. 1975. Standard Methods for the Examination of Water and Wastewater, 14th Edition, Washington, $\overline{D C}$.

Bel1, N. E. 1980. Solvent Extraction of Phenolics from Water. M.S. Thesis in Chemical Engineering, University of California, Berkeley, CA.

Brown, W. V. 1963. "Economics of Recovering Acetic Acid." Chem. Eng. Prog., Vol. 59, No. 10, pp. 65-68.

Chemical Marketing Reporter. June 12, 1981.

Dean, J. A. 1973. Lange's Handbook of Chemistry. 11th Edition, McGraw-Hi11, New York, NY.

Earhart, J. P. et al. 1976. Extraction of Chemical Pollutants from Industrial Wastewaters with Volatile Solvents. EPA-600/2-76-220.

English, C. J. 1981. Treatment of Biomass Gasification Wastewaters by Wet Air 0xidation. - Report to the U.S. Department of Energy by Pacific Northwest Laboratory, Richland, WA.

Greminger, D. C. 1979. Extraction of Phenols from Coal Conversion Process Condensate Waters. M.S. Thesis in Chemical Engineering, University of California, Berkeley, CA. Also Lawrence Berkeley Laboratory Report LBL-9177.

Hanson, C. 1968. "Solvent Extraction: Theory, Equipment, Commercial Operations, and Economics." Chem. Eng., August 16, p. 97.

Helsel, R. W. 1978. "Removing Carboxylic Acids from Aqueous Wastes." Chem. Eng. Prog., May, pp. 55-59 (also reported in Lyman, 1978).

Kao, C. H. 1980. Extraction of Waste Water from Biomass Gasification. M.S. Thes is in Chemical Engineering, Texas Tech University, Lubbock, TX.

Kiezyk, P. R. and D. Mackay. 1971. "Wastewater Treatment by Solvent Extraction." Can. J. Chem. Eng., Vol. 49, pp. 747-752.

Kohn, P. M. 1976. "New Extraction Process Wins Acetic Acid from Waste Streams." Chem. Eng., March 19.

Leo, A., C. Hansch and D. Elkins. 1971. "Partition Coefficients and Their Uses." Chemical Reviews, Vol. 71, No. 6, pp. 525-592.

Lorton, G. A. 1977. Removal of Phenols from Process Condensate. C. F. Braun and Company, Report FE-2240-39. Prepared for the U.S. Department of Energy and Gas Research Institute. 
Lyman, W. J. 1978. "Liquid-Liquid Extraction of Organics." In: Unit Operations for Treatment of Hazardous Industrial Wastes. J. B. Berkowitz et a1., pp. 680-709. Noyes Data Corporation, Park Ridge, NJ.

Maxham, J. V. 1981. "Treatment of Biomass Gasification Wastewater." Presented at the 12th Biomass Thermochemical Conversion Contractors Meeting, Washington, D.C.

Perry, R. H. and C. H. Chilton. 1973. Handbook of Chemical Engineering. 5th Edition, McGraw-Hill, New York, NY.

Petty, S. E., S. D. Eliason and M. M. Laegreid. 1981. Treatment of Biomass Gasification Wastewaters Using Reverse Osmosis. Prepared for the U.S. Department of Energy by Pacific Northwest Laboratory.

Siller, D. 1976. Analys is of Waste Streams from the SGFM Reactor. M.S. Thes is, Department of Chemistry, Texas Tech University, Lubbock, TX.

Wardell, J. M. and C. J. King. 1978. "Solvent Equilibria for Extraction of Carboxylic Acids from Water." J. Chem. Eng. Data, Vol. 23, No. 2, pp. 144-148.

Weaver, D. G. and W. A. Biggs, Jr. 1961. "Pulp-Mi.11 Waste Liquor." Ind. Eng. Chem., Vol. 53, No. 10, pp. 773-778. 


\section{DISTRIBUTION}

No. of

Copies

\section{OFFSITE}

A. A. Churm

DOE Patent Division

9800 South Cass Avenue

Argonne, IL 60439

Ray Costello

Biomass Energy Systems Division

U.S. Department of Energy

600 E Street, N. W.

Mail Stop 404

Washington, DC 20545

27 DOE Technical Information Center
J. V. Maxham
Institute of Paper Chemistry
Appleton, WI 54911

C. J. King

Chairman and Professor

Department of Chemical Engineering

University of California

Berkeley, CA 94720

ONSITE

Richland Operations Office

H. E. Ransom

20 Pacific Northwest Laboratory

D. B. Cearlock

G. W. Dawson

N. E. Bell (10)

A. F. Gasperino

Publishing Coordination (2)

Technical Information (5) 
